\title{
SURGICAL TREATMENT OF PLEURAL EMPYEMA - OUR RESULTS
}

Goran Kondov ${ }^{1}$, Zoran Spirovski ${ }^{1}$, Irena Kondova-Topuzovska ${ }^{2}$, Anita Kokareva ${ }^{3}$, Risto Colanceski ${ }^{1}$, M. Srceva ${ }^{3}$, Borislav Kondov ${ }^{1}$, I Dzikovski ${ }^{1}$, N. Toleska-Dimitrovska ${ }^{1}$, Sanja Petrusevska-Marinkovic ${ }^{2}$

${ }^{1}$ University Thoracovascular Surgery Clinic, Medical Faculty, Skopje, R. Macedonia,

${ }^{2}$ University Infectious Diseases Clinic, Medical Faculty, Skopje, R. Macedonia,

${ }^{3}$ University Anesthesia and Reanimation Clinic, Medical Faculty, Skopje, R. Macedonia

Corresponding author: Prof. Dr. Kondov Goran, MD, PhD. University Clinic of Thoracovascular Surgery, Clinical Centre, Medical Faculty, Mother Tereza 17, 1000 Skopje, R. Macedonia, Tel.: 0038970252 010, E-mail:kondov@yahoo.com

\section{ABSTRACT}

Pleural infection is a frequent clinical condition. Prompt treatment has been shown to reduce morbidity, mortality and duration of hospital stay. Unfortunately, advanced stages of empyema need to use extensive surgery - decortications or thoracoplasty. Early recognition of the parapneumonic effusion and the adequate treatment with thoracentesis or pleural drainage, which is minimally invasive, is possible not to prograde the process and not to become empyema.

Aim: To analyze the results of the surgical treatment in patients with empyema treated at Clinic for thoracic surgery.

Material and methods: In the retrospective study we analyzed 234 patients with empyema which were treated at the Clinic for Thoracic Surgery in 5 year period (2011-2015). The mean age of the patients was 51.94 years. They were treated with pleural drainage, decortications or thoracoplasty. Results: With pleural drainage were treated 165/234 (70.51\%) patients, of which successfully were finished $124 / 165(75.15 \%)$, but $41 / 165(24.85 \%)$ were indicated after the decortications. A total of 108/234 $(46.15 \%)$ were treated with decortications from which, primary decortications were indicated in 67/234 (28.63\%) patients. 5/234 (2.14\%) patients were treated with thoracoplasty -3 of the patients with decortications and 2 with primary indicated thoracoplasty according to the local findings, long term untreated empyema and bad general condition. The Mean hospitalization was 17.4 days, of which 13.4 days after surgery. In the group with primary drainage it was detected a lethal outcome in 7/124 (5.64\%) patients, 5/105 (4.76\%) in the group with decortications and $2 / 5(40 \%)$ in the group with thoracoplasty.

Conclusion: Early detection of the parapneumonic effusion and the adequate treatment will prevent the appearance of empyema. If the empyema is detected it is necessary as early as possible to start the treatment with minimally invasive pleural drainage. In earlier stages it is possible to use less invasive decortications, using VATS than the open thoracotomy decortication which is more extensive surgical intervention.

Key words: pleural empyema, decortication, thoracic drainage, thoracoplasty

\section{INTRODUCTION}

The older population very often has comorbidities (heart disease, liver disease, renal disease), and the large number of patients with immuno- compromised condition (alcohol use, drug abuse, HIV infection) and with frequent lung infection results in frequent affection of the pleura, which results in appearing of the pleural infection that in the end ends with pleural empyema. The per- 
sistence of empyema after pneumonia results in big rate of mortality (5-20\%). [1-4]

Unfortunately, the advanced stages of empyema need to use extensive surgery- decortications or thoracoplasty. The prompt treatment, as early as possible, has been shown to reduce morbidity, mortality and the duration of hospital stay.

With the early recognition of the parapneumonic effusion and the adequate treatment with thoracentesis or the pleural drainage, which is minimally invasive, it is possible to prevent progression of the process and not to become empyema. $[5,6,7,8]$

The aim of this study was to analyze the results of the surgical treatment in patients with empyema treated at the Clinic for Thoracic Surgery. The analysis of the results of the surgically treated patients will give recommendations for the treatment of the parapneumonic effusion and the empyema-complications of pneumonia.

\section{MATERIAL AND METHODS}

In the retrospective study we analyzed 234 patients with empyema which were treated at the Clinic for thoracic surgery in 5 year period (20112015). The mean age of the patients was 51.94 years. They were treated with pleural drainage, decortication or thoracoplasty.

The diagnosis of the empyema was made with $X$-ray of the chest, ultrasound of the pleura and thoracentesis of the pleural effusion. Initial lung $\mathrm{X}$-rays were taken for all patients at the Institute of Radiology, Medical Faculty in Skopje. The pleural fluid obtained with the thoracentesis has been sent for a series of biochemical, cytological, histopathological and microbiological tests for determination of the nature of the effusion. The analysis of the pleural fluid was made at the Clinical Biochemical Laboratory (Medical Faculty Skopje), at the Institute for Microbiology (Medical Faculty Skopje) and the cytological examination of the pleural fluid at the Institute of Cytopathology at the Clinic for Oncology. For the patients planed for surgical treatment in general anesthesia a computer tomography of the chest at the Institute for radiology was done, a complete blood biochemical laboratory analysis at the Clinical Biochemical Laboratory, ultrasonography of the heart at the Clinic for Cardiology, respiratory test at the Clinic for Pulmonology, and an analysis of the blood for coagulations and fibrinolysis factors at the Institute of Transfusion Medicine, Faculty of Medicine in Skopje.
The surgical treatment of the empyema was performed with pleural drainage, decortication or thoracoplasty.

Pleural drainage was done in local anesthesia, and a wide thoracic drain was placed where the thorax was previously marked under the ultrasonography.

The decortication was done in general anesthesia with posterolateral thoracotomy. After the thoracotomy, the thickened parietal and visceral pleura were removed, by removing numerous trapped spaces filled with fluid or pus, and released trapped lung.

The thoracoplasty was done in general anesthesia, where 2 to 7 ribs were removed, in order to descend down the chest muscles and to obliterate the underling space, up to lung.

The end point of the surgical treatment (successful treatment) of the pleural empyema is: evacuation of the pus, enabling of re-expansion of the lung, obliteration of the dead space (if persists) and removing of the thickened pleura, especially the trapped lung (if persists).

The histological examination of the pleural fluid and the material removed from the surgical intervention were examined at the Institute for pathology (Medical faculty Skopje).

\section{RESULTS}

We analyzed the results of 5 years (20112015) in the period of which 234 patients with pleural empyema were treated, of which 165 $(70.51 \%)$ were treated with pleural drainage, 108 $(46.15 \%)$ were treated with decortications and $5(2.14 \%)$ with thoracoplasty. The results of the surgical treatment in the patients with empyema are shown in Graph 1 and Table 1.

The mean age of the total 234 patients with empyema was 51.94 years, in the group with pleural drainage the mean age was 49.2 years, in the group with decortications 54.9 years and in the group with thoracoplasty 58.5 years. (Table 2)

The mean hospitalization of the patients was 17.4 days, of which 13.4 days after surgery. The mean hospitalization before and after surgery in all groups of patients is presented in Table 3.

In the group with primary drainage lethal outcome was detected in $7(5.6 \%)$ patients, $5(4.7 \%)$ in the group with decortications and $2(40 \%)$ in the group with thoracoplasty. (Table 4)

In the group with pleural drainage there were not patients only in the exudative phase of empyema. The mean age was 49.2 years, but with bigger 


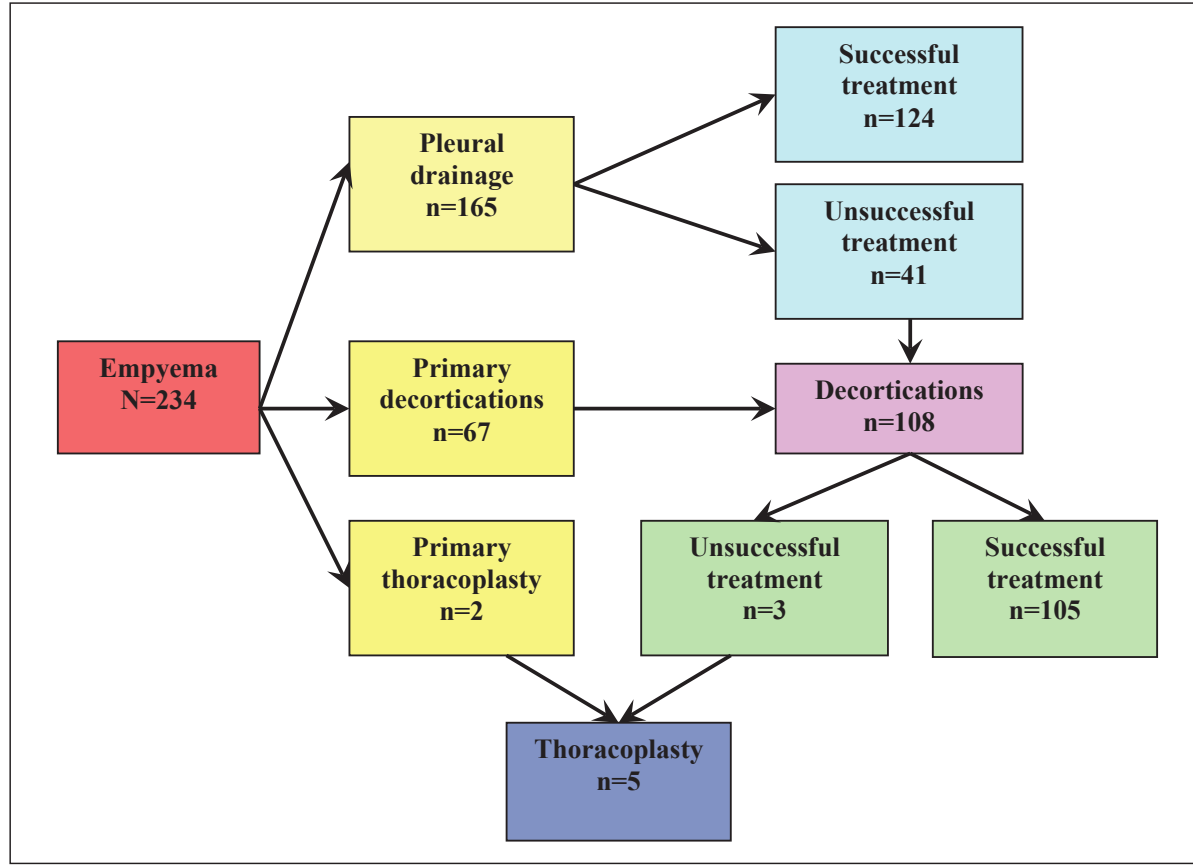

Graph 1. Results of surgical treatment in patients with empyema.

Table 1. Results of surgical treatment in patients with empyema.

\begin{tabular}{|l|c|c|c|}
\hline Surgery & $\begin{array}{c}\text { patients } \\
(\mathbf{n = 2 3 4 )}\end{array}$ & $\begin{array}{c}\text { successful treatment } \\
(\mathbf{\%})\end{array}$ & $\begin{array}{c}\text { unsuccessful treatment } \\
(\mathbf{\%})\end{array}$ \\
\hline Pleural drainage & 165 & $124(75.15 \%)$ & $41(24.85 \%)$ \\
\hline Decortication & 108 & $105(97.22 \%)$ & $3(2.78 \%)$ \\
\hline Thoracoplasty & 5 & & \\
\hline
\end{tabular}

Table 2. Age of surgically treated patients with empyema

\begin{tabular}{|l|c|c|}
\hline Surgery & $\begin{array}{c}\text { patients } \\
(\mathbf{\%})\end{array}$ & $\begin{array}{c}\text { mean age } \\
\text { (years) }\end{array}$ \\
\hline Pleural drainage & $124(52.99 \%)$ & 49.2 \\
\hline Decortication & $105(45.45 \%)$ & 54.9 \\
\hline Thoracoplasty & $5(2.14 \%)$ & 58.5 \\
\hline Total & 234 & 51.94 \\
\hline
\end{tabular}

Table 3. Mean hospitalization of surgically treated patients with empyema

\begin{tabular}{|l|c|c|c|c|}
\hline Surgery & $\begin{array}{c}\text { patients } \\
(\mathbf{\%})\end{array}$ & $\begin{array}{c}\text { hospitalization before } \\
\text { surgery - days }\end{array}$ & $\begin{array}{c}\text { hospitalization after } \\
\text { surgery - days }\end{array}$ & $\begin{array}{c}\text { mean } \\
\text { hospitalization - days }\end{array}$ \\
\hline Pleural drainage & $124(52.99 \%)$ & 0.8 & 10.6 & 11.4 \\
\hline Decortication & $105(45.45 \%)$ & 7.4 & 15.9 & 23.3 \\
\hline Thoracoplasty & $5(2.14 \%)$ & 12.3 & 29.9 & 42.2 \\
\hline Total & 234 & 4.0 & 13.4 & 17.4 \\
\hline
\end{tabular}

Table 4. Lethal outcome of surgically treated patients with empyema

\begin{tabular}{|l|c|c|}
\hline Surgery & $\begin{array}{c}\text { patients } \\
(\mathbf{\%})\end{array}$ & $\begin{array}{c}\text { lethal outcome } \\
(\mathbf{\%})\end{array}$ \\
\hline Pleural drainage & $124(52.99 \%)$ & $7(5.6 \%)$ \\
\hline Decortication & $105(45.45 \%)$ & $5(4.7 \%)$ \\
\hline Thoracoplasty & $5(2.14 \%)$ & $2(40 \%)$ \\
\hline Total & 234 & $14(6 \%)$ \\
\hline
\end{tabular}


deviation than in the age in the whole group. In this group the mean hospitalization was shorter, 11.4 days. In this group there were also older patients in bad condition, where it was impossible to plan serious surgical intervention. This is the reason why so many lethal outcomes were detected in this group, in 7 (5.6\%). Unfortunately, in 41/165 $(24.85 \%)$ patients the treatment with pleural drainage was insufficient, and further surgical treatment was necessary - thoracotomy with decortication.

In the group with decortications patients in fibrin purulent phase of empyema were treated. These patients were prepared before the surgery with reanimation, which continues after surgery. The mean hospitalization of those patients was 23.3 days. The lethal outcome was detected in 5 $(4.7 \%)$. In this group were detected many early and late morbidities: infection of the wound in 16 $(14.8 \%)$, pleural encapsulates in $42(38.9 \%)$, not complete re-expansion of the lung in $18(16.7 \%)$, atelectasis in 16 (14.8\%), febrile conditions in 25 (23.1\%), pleurocutaneous fistulas in $2(1.8 \%)$. Many of the complications were treated conservatively with introducing another antibiotic according to antibiogram, placing another pleural drain, thoracentesis, physical respiratory therapy, bronchoscopy with broncholavage. In 11 patients mechanical ventilation was used 2-11 days after surgery. In $3(2.8 \%)$ patients, according to the complications indicated afterwards, thoracoplasty was done. Unfortunately, in the pathohistological examination of this group fibrinopurulent stage was found in all, in $29(26.85 \%)$ in the initial phase in organization of the peel, and in 5 an underlying malignant disease of the lung.

In the group with thoracoplasty, there were only $5(2.4 \%)$ patients, in bad condition, in the chronic phase of empyema where is impossible to perform decortication. Unfortunately, in $2(40 \%)$ patients underlying malignant disease was found. Lethal outcome was detected in $2(40 \%)$ patients.

\section{DISCUSSION}

In order to understand the treatment of pleural empyema it is necessary to understand the pathophysiology of the genesis of empyema. Pneumonia, which is the most frequent reason for empyema, is caused with the inflammatory reaction of both pleural leaves. This is the reason for uncomplicated parapneumonic effusion. The invasion of the bacteria in the fluid and the phagocyte from the host, causes changes in fluid, transformation of the glucose in lactic acid, with changes in the levels of glucose (decrease), reducing the $\mathrm{pH}$ values, and the liquid becomes turbid. This is the exudative phase of empyema, and lasts 7 to 14 days. After that the fibrin from the effusion, deposits on the parietal and visceral leaves, and the fluid becomes more turbid and becomes pus. This is the fibrin purulent phase which lasts 2-4 weeks. In the end, in the organization phase the fibroblast becomes between the fibrin deposits and transform in fibrosis, which is thicker and adherent to the pleural leaflets. Also, compartments in the fluid were formed, which is more and more turbid-pus. The thickening of the peel to the pleural leaflets becomes more than 1 centimeter, it is hard, and also involves with the vessels from the lungs. If you try to move up this deposit you will damage the lung parenchyma. $[5,6,9]$

These changes of the pleura were classified by Light (2006) and also by the American Thoracic Surgery in 1962 in three phases (acute, fibrinopurulent and chronic). [5,6]

The surgical treatment of the pleural empyema largely depends on the stage of the disease.

The acute exudative phase is possible to treat with thoracic drainage combined or not with fibrinolytic therapy to resolve the problem. We prefer to start treatment with pleural drainage, especially if we know that many of the patients come as urgent. This is reason why from 234 patients, 165 $(70.51 \%)$ start with the pleural drainage. But only patients which were in the acute exudative phase have had chance for successful treatment, and in our series the successful finis was only in 124 $(75 \%)$. Nevertheless, in the other patients decortication was made, and after that other examinations were done (microbiology, cytology of the fluid), ultrasonography of the chest and CT of the thorax. In this group, there were mixed patients by age, general conditions and comorbidities. The mean age was 49.2 years, which is less than in the other groups. The mean hospitalization was shorter, 11.4 days. In this group there were also older patients in bad condition, with many comorbidities, which is the reason why so many lethal outcomes were detected in this group, in $7(5.6 \%)$, which corresponded with the literature. [8] We didn't use fibrinolytic therapy, which corresponded with few papers. $[4,11]$

In the fibrinopurulent phase it is necessary to think about decortication which can be done with classical thoracotomy or with videothoracoscopy (VATS). The use of VATS is necessary to be as early as possible in the fibrinopurulent phase where only thin deposits of fibrin persist. The mean hos- 
pitalization of those patients was 23.3 days, which is longer than in the first group, but these were respectively according to the surgical treatment, which is very often complicated with early and late morbidities. Lethal outcome was detected in 5 (4.7\%). Knowing that this were septic patents, with many comorbidities, these results are acceptable, which is according to the literature. [2,10]

It is maybe more reasonable before starting any surgical treatment to do a complete examination, ultrasonography of the chest, complete analysis of the pleural fluid, CT of the chest, examination of the lung reserves (spirometry, bronchoscopy), examination of the heart reserves (ultrasonography) and to plan the further treatment. If we find thickened deposits of parietal and especially visceral pleura, which trap the lung, and if there were multiloculations maybe it is better to plan the decortication from the beginning. Few papers refer better early and late results if the fibrinopurulent stage is treated with decortication, compared with the pleural drainage. $[10,12,13]$

If we find early signs of fibrinopurulent phase it can be treated with VATS decortication, and to release the trapped lung. With this procedure it is possible minimally invasive to remove the fibrin deposits to the pleural leaflets. $[10,11]$ This is important not to lose time, and as fast as possible to make ultrasonography of the chest and CT of the chest.

The fibrosing of the peel and the involvement with the vessels, make decortication impossible, the lung remains collapsed and trapped, so in this situation it needs to plan some kind of thoracoplasty to close the dead space or to make partial resection of the rib and to make open window for continuous drainage of the pus. With thoracoplasty there were only $5(2.14 \%)$ patients in bad condition, in the chronic phase of empyema when it is impossible to make decortication. Lethal outcome was detected in $2(40 \%)$ patients.

Knowing the pathogenesis of the development of pleural empyema, especially the short time between the different phases of empyema, it is very important immediately to make adequate diagnosis using ultrasound of the pleura, CT of the chest, biochemical analyses of the effusion, microbiology of the effusion. After that immediately to determine the stage (phase) to decide the therapeutic and surgical approach. $[7,8,9]$

Very practical are the suggestions of Hamm who suggest if the liquid is not clear or purulent, and if on ultrasonography there is no loculation, to perform pleural drainage; if is loculated to try with fibrinolytics 24-48 hours with pleural drainage, or to try early decortication with VATS. If there isn't success with VATS than open thoracotomy and decortication are necessary. [13]

The main problem in our group is the delay in diagnosis and the beginning with the treatment, which is the reason for such a big number of decortications of 108 (46.15\%). Mainly, patients come in fibrinopurulent stage of empyema, many with initial process of organization and at some patients in the chronic stage of empyema. In this stage we can plan only open thoracotomy and decortication, which is big and mutilant surgical intervention.

If general doctors know that $50 \%$ of patients with pneumonia will produce pleural effusion (parapneumonic effusion) (Light 2,3), which compromises the further treatment, the pleura needs to be controlled with ultrasound examination of the pleura, and when this exudates appears to start the aggressive treatment, thoracentesis. With this approach it is possible to prevent the further progress of the illness and the further progress of the parapneumonic effusion to pleural empyema.

Furthermore, if the diagnosis is in the early phases of empyema (Light 4) (exudative phase according ATS) and is adequately treated with antibiotic and pleural drainage, it is possible to prevent the further progress, or it is possible to use VATS decortication, as minimally invasive surgical procedure. $[7,11,13]$

\section{CONCLUSION}

The early detection of the parapneumonic effusion and the adequate treatment will prevent the appearance of empyema. If the empyema is detected it is necessary as early as possible to start the treatment with the minimally invasive pleural drainage. In the earlier stages it is possible to use less invasive decortications, using VATS instead of the open thoracotomy decortications, which is more extensive surgical intervention.

\section{Conflict of interest}

We do not have a conflict of interest to declare

\section{REFERENCES}

1. Torres A, Peetermans WE, Viegi G, Blasi F. Risk factors for community-acquired pneumonia in adults in Europe: a literature review. Thorax 2013 Nov;68(11):1057e65. 
2. Ferguson AD, Prescott RJ, Selkon JB, Watson $\mathrm{D}$, Swinburn $\mathrm{CR} .=$ The clinical course and management of thoracic empyema.QJM 1996;89(4):285e9.

3. Davies CW, Kearney SE, Gleeson FV, Davies RJ. Predictors of outcome and long-term survival in patients with pleural infection. Am J Respir Crit Care Med 1999;160:1682e7.

4. Rahman NM, Maskell NA, West A, Teoh R, Arnold A, Mackinlay C. Intrapleural use of tissue plasminogen activator and DNase in pleural infection. N Engl J Med 2011;365:518e26.

5. Light RW. Parapneumonic effusions and empyema. Proc Thorac Soc 2006;3:75e80

6. American Thoracic Society. Management of nontuberculousempyema. Am Rev Respir Dis 1962;85:935e6.

7. Ke-Cheng Chen, Hsuan-Yu Chen, Jou-Wei Lin, Yu-Ting Tseng, Shuenn-Wen Kuo, PeiMing Huang ,Hsao-Hsun Hsu, Jang-Ming Lee, Jin-Shing Chen, Hong-Shiee Lai -Acute thoracic empyema: Clinicalcharacteristics and outcome analysisof video-assisted thoracoscopic surgery-Journal of the Formosan Medical Association (2014) 113, 210e218

8. Michael Schweigert, Norbert Solymosi, Attila Dubecz, Marta Jimenez Fernandez, Rudolf J. Stadlhuber, Dietmar Ofner, Hubert J. Stein Surgery for parapneumonic pleural empyema
eWhat influence does the rising prevalence of multimorbidity and advanced age has on the current outcome - The surgeon 14 (2016) 69 e7

9. Victoria Villena Garrido, Enrique Cases Viedma, Alberto Fernández Villar, Alicia de Pablo Gafas, Esteban Pérez Rodríguez, José Manuel Porcel Pérez, Francisco Rodríguez Panadero, Carlos Ruiz Martínez, Ángel Salvatierra Velázquez, Luis Valdés Cuadrado- Recommendations of Diagnosis and Treatment of Pleural Effusion. Update Normativa sobre el diagnóstico y tratamiento del derrame pleural. Actualización;Arch Bronconeumol 2014;50:235-49 - Vol. 50 Num.6

10. Farjah F, Symons RG, Krishnadasan B, Wood DE, Flum DR. Management of pleural space infections: a population-basedanalysis. J Thorac Cardiovasc Surg 2007;133:346e51.

11. Maskell NA, Davies CW, Nunn AJ, Hedley EL, Gleeson FV,Miller R, et al. U.K.controlled trial of intrapleural streptokinase for pleural infection. N Engl J Med 2005;352:865e74.

12. Shin JA, Chang YS, Kim TH, Haam SJ, Kim HJ, Ahn CM, et al. Surgical decortication as the first-line treatment for pleural empyema. J Thorac Cardiovasc Surg 2013;145:933e9.

13. H Hamm, RW Light. Parapneumonic effusion and empyema European Respiratory Journal 1997 10: 1150-1156 


\section{ХИРУРШКИ ТРЕТМАН НА ПЛЕВРАЛНА ЕМПИЕМА - НАШИТЕ РЕЗУЛТАТИ}

Горан Кондовв ${ }^{1}$ Зоран Спировски ${ }^{1}$, Ирена Кондова-Топузовска ${ }^{2}$, Анита Кокарева ${ }^{3}$, Ристо Чоланчески ${ }^{1}$, М. Срцева ${ }^{3}$, Борислав Кондов ${ }^{1}$, И. Џиковски ${ }^{1}$ Н. Толеска Димитровска ${ }^{1}$, Сања Петрушевска-Маринковиќ ${ }^{2}$

${ }^{1}$ Универзитетска клиника за торакална и васкуларна хирургија, Медицински факултет, Скопје, Р. Македонија

${ }^{2}$ Универзитетска клиника за инфективни болести, Медицински факултет, Скопје, Р. Македонија

${ }^{3}$ Универзитетска клиника за анестезија и реанимација, Медицински факултет, Скопје, Р. Македонија

\section{Резиме}

Плевралните инфекции се чести. Брзиот третман го намалува морбидитетот, морталитетот и должината на хоспиталниот престој. За несреќа напреднатите стадиуми на емпием захтеваат примена на екстензивна хирургија, како декортикација или торакопластика. Раната детекција на парапнеумоничните изливи и адекватна терапија на истите со примена на торакоцентеза или плеврална дренажа, кои се минимално инвазивни процедури, можно е да го спречи прогресот на болеста да не настане емпием.

Цел:

Анализа на резултатите од хируршкиот третман кај пациентите со емпием третирани на Клиниката за торакална хирургија.

\section{Материјал и методи}

Во ретроспективна студија анализирани се 234 пациенти емпием третирани на Клиниката за торакална хирургија во 5 годишен период (2011-2015). Средната возраст на пациентите беше 51,94 години. Пациентите беа третирани со плеврална дренажа, декортикација и торакопластика.

\section{Ресултати:}

Со плеврална дренажа беа третирани 165/234 (70,51\%) пациенти, од кои завршен е третманот успешно кај 124/165 (75.15\%), но кај 41/165 (24,85\%) покасно захтевале примена на декортикација. Со декортикација вкупно беа третирани 108/234 (46,15\%) од кои примарна декортикација е индицирана кај 67/234 (28,63\%) пациенти. Со торакопластика беа третирани 5/234 (2,14\%) пациенти- 3 од пациентите со декортикација и кај 2 била применета примарна торакопластика која е индицирана како последица на локален наод, долго време не третиран емпием или генерално општа тешка состојба која не може да поднесе декортикација. Средно време на хоспитализација беше 17.4 дена, од кои 13.4 дена престој по операција кај хируршки третираните пациенти. Во групата со примарна дренажа смртен исход бил детектиран кај 7/124 (5,6\%), кај 5/105 (4,7\%) во група на декортикација и кај 2/5 (40\%) во група со торакопластика.

\section{Заклучок:}

Рана детекција на парапнеумоничен излив и адекватен третман може да превенира појава на емпием. Доколку се детектира емпием, неопходно е што порано да се започне со третман пред се со минимално инвазивни хируршки процедури-торакална дренажа. Во раните стадиуми возможно е да се употреби помалку инвазивен тип на декортикација, користејќи ВАТС, наместо класична отворена торакотомија и декортикација која е поагресивна хируршка интервенција.

Клучни зборови: плеврален емпием, декортикација, торакална дренажа 